\title{
An Update On The Possible Incorporation Of IFRS Into The U.S. Financial Reporting System
}

\author{
Wing W. Poon, Montclair State University, USA
}

\begin{abstract}
The SEC issued the "Commission Statement in Support of Convergence and Global Accounting Standards" in February 2010 to reaffirm its position that IFRS was best positioned to serve as the single set of high-quality globally accepted accounting standards and indicated that it would not incorporate IFRS into the financial reporting system for U.S. issuers unless such a change is in the best interest of U.S. investors and capital markets and that a determination was expected to be made in 2011 as to whether, when, and how to incorporate IFRS into the financial reporting system for U.S. issuers. It is now 2015 and the SEC still has not yet made a decision. Nonetheless, based on the statements given by the SEC Chief Accountant James Schnurr at the Baruch College Financial Reporting Conference in May 2015, it appears that the SEC might make a decision really soon. The wait for the SEC's decision might finally be over. This paper provides an update on the possible incorporation of IFRS into the U.S. financial reporting system.
\end{abstract}

Keywords: IFRS; International Financial Reporting Standards; Global Convergence; Work Plan; Convergence Approach; Endorsement Approach; "Condorsement" Approach

\section{INTRODUCTION}

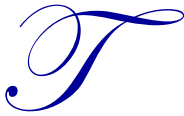

he Securities and Exchange Commission (SEC) issued the "Commission Statement in Support of Convergence and Global Accounting Standards" (2010 Statement) in February 2010 to reaffirm its position that International Financial Reporting Standards (IFRS) ${ }^{1}$ was best positioned to serve as the single set of high-quality globally accepted accounting standards and indicated that it would not incorporate IFRS into the financial reporting system for U.S. issuers unless such a change is in the best interest of U.S. investors and capital markets and that a determination was expected to be made in 2011 as to whether, when, and how to incorporate IFRS into the financial reporting system for U.S. issuers. ${ }^{2}$ The "Work Plan for the Consideration of Incorporating International Financial Reporting Standards into the Financial Reporting System for U.S. Issuers" (IFRS Work Plan) included as an appendix to the 2010 Statement, detailed six specific areas of consideration for the SEC staff to address before a potential move to a system incorporating IFRS. It is now 2015 and the SEC still has not yet made a decision. Nonetheless, based on the statements given by the SEC Chief Accountant James Schnurr at the Baruch College Financial Reporting Conference in May 2015, it appears that the SEC might make a decision really soon. The wait for the SEC's decision might finally be over. This paper provides an update on the possible incorporation of IFRS into the U.S. financial reporting system.

\section{IFRS}

The international standard-setting process began in 1973 with the formation of the International Accounting Standards Committee (IASC) by representatives from many of the large developed countries. The goal of the IASC

\footnotetext{
${ }^{1}$ The term "IFRS" refers to IFRS as issued by the International Accounting Standards Board and those International Accounting Standards (IAS) not yet superseded by IFRS, unless otherwise noted.

${ }^{2}$ U.S. issuers are those U.S. companies that have publicly listed securities and have to file their financial statements with the SEC. Since 2008, foreign companies that have publicly listed securities in the U.S. have been allowed to use IFRS, without reconciliation to U.S. GAAP, in their SEC filings.
} 
was to create accounting standards that could be used by developing and smaller countries that were unable to establish their own standards. With the continuing globalization of business and finance, investors, regulators, large companies, and accounting firms began to realize the importance of a single set of globally accepted accounting standards. In 1998, a core set of IAS was completed by the IASC and in 2000, the International Organization of Securities Commission, of which the SEC is a member, recommended that its members allow companies to use these standards in cross-border listings. In 2001, the IASC Foundation was created and the International Accounting Standards Board (IASB) was established as the successor organization to the IASC and was charged for the development of IFRS (the IASC Foundation changed its name to IFRS Foundation in 2010, as a result of the amendments to its Constitution). In 2002, the Financial Accounting Standards Board (FASB) and the IASB issued a Memorandum of Understanding (MoU) known as the Norwalk Agreement, acknowledging their joint commitment in developing high quality, compatible accounting standards that could be used for both domestic and cross-border financial reporting. The two Boards were committed to improving and converging their respective accounting standards. The differences between U.S. GAAP and IFRS have become fewer and narrower as a result of the convergence project (the latest example is the issuance, in May 2014, of the essentially identical revenue recognition standards by the two Boards). The first widespread use of IFRS was in 2005 with the incorporation of IFRS in the European Union. In 2007, the SEC issued the "Concept Release on Allowing U.S. Issuers to Prepare Financial Statements in Accordance with International Financial Reporting Standards" (2007 Concept Release) to request public comments on whether U.S. issuers should be allowed to prepare financial statements in accordance with IFRS. Beginning in 2008, the SEC started to allow foreign companies that listed securities in the U.S. to file financial statements prepared in accordance with IFRS without reconciliation to U.S. GAAP. In November 2008, the SEC issued the "Roadmap for the Potential Use of Financial Statements Prepared in Accordance with International Financial Reporting Standards by U.S. Issuers" (2008 Roadmap) to propose a roadmap of its consideration in the use of IFRS by U.S. issuers.

\section{SEC IFRS WORK PLAN}

In February 2010, the SEC issued the "Commission Statement in Support of Convergence and Global Accounting Standards" to reaffirm its position that IFRS was best positioned to serve as the single set of high-quality globally accepted accounting standards. The SEC IFRS Work Plan, published as an appendix to the 2010 Statement, detailed six specific areas of consideration for the SEC staff to address before a potential move to a system incorporating IFRS for U.S. issuers. These areas are the quality of IFRS, the independence of the IASB, the investors' knowledge of IFRS, the impact on the U.S. regulatory environment, the impact on U.S. issuers, and the human capital readiness. These are the issues and concerns raised either in the 2008 Roadmap or by the respondents to the 2008 Roadmap.

\section{“CONDORSEMENT" APPROACH}

In May 2011, the SEC staff published a paper, "Exploring a Possible Method of Incorporation," (2011 Possible Method) as an update to the IFRS Work Plan. This staff paper outlined one possible approach for incorporating IFRS into the financial reporting system for U.S. issuers if the SEC were to decide to incorporate IFRS. As this approach blends aspects of both a convergence approach and an endorsement approach, it is termed "condorsement." Under the "condorsement" approach outlined in the 2011 Possible Method, U.S. GAAP would be retained, but the FASB would incorporate IFRS into U.S. GAAP over a period of five to seven years. During this transitional period, existing differences between IFRS and U.S. GAAP would be addressed with the objective that a U.S. issuer compliant with U.S. GAAP should be able to represent that it is compliant with IFRS by the end of the transitional period. The FASB would incorporate newly issued and amended IFRS into U.S. GAAP according to an established endorsement protocol such that the FASB would be able to modify or supplement IFRS when appropriate.

The SEC staff pointed out several advantages of the "condorsement" approach in the 2011 Possible Method. It believed that the approach could allow for a more flexible transition strategy in which the FASB would evaluate each of the IFRS individually to determine the timing and manner of transition and that a gradual incorporation of IFRS would require U.S. issuers and investors to adjust to fewer new standards in any given period. In addition, the SEC staff argued that the incorporation of IFRS by FASB endorsement would allow the option of modifying or supplementing IFRS when necessary and that retaining U.S. GAAP as the statutory basis of financial reporting for 
U.S. issuers would reduce the costs and complexity of IFRS incorporation for both regulators and issuers as U.S. laws, regulatory requirements and guidelines and contractual documents are often made reference to U.S. GAAP.

\section{COMPARISON OF U.S. GAAP AND IFRS}

The SEC staff published two more papers related to the IFRS Work Plan in November 2011. The first paper, " $\underline{A}$ Comparison of U.S. GAAP and IFRS," compared U.S. GAAP to IFRS. The SEC staff noted that U.S. GAAP generally contains more detailed, specific requirements than does IFRS as IFRS usually provides a broad principle to be applied across industries with limited stated exceptions or specific guidance. It also noted that the differences in the conceptual frameworks of the FASB and IASB might have contributed to the differences of current U.S. GAAP and IFRS and future standard-setting. This SEC staff paper confirmed the general observations that there are still many differences between U.S. GAAP and IFRS despite the convergence efforts. As the FASB and the IASB had recently abandoned their efforts in developing a common conceptual framework, it is highly likely that they will sometimes follow different paths in future standard-setting (the latest example is the substantially different paths taken by the two Boards in formulating their financial instrument standards). It is thus highly questionable that differences between U.S. GAAP and IFRS could be addressed to achieve the objective stated in the 2011 Possible Method that a U.S. issuer compliant with U.S. GAAP should be able to represent that it is compliant with IFRS by the end of the transitional period as suggested in the 2011 Possible Method.

\section{IFRS IN PRACTICE}

The second paper published by the SEC staff in November 2011, “An Analysis of IFRS in Practice," examined how foreign companies in the Fortune Global 500 had used IFRS ${ }^{3}$ in their financial reporting. It reported that while these financial statements generally appeared to comply with IFRS requirements, the comparability of these financial statements were adversely affected by the diversity in the application of IFRS and that this diversity was attributed to either the options permitted by IFRS, the absence of IFRS guidance, or in some cases even the apparent noncompliance with IFRS. It is important to note that, as stated by the SEC staff, this staff paper did not attempt to compare the use of IFRS in practice to the use of U.S. GAAP in practice. Therefore, it is not possible to draw any conclusion from the staff paper regarding the degree of consistency in the application and the enforcement of IFRS in comparison to those of U.S. GAAP.

\section{FINAL STAFF REPORT}

The SEC Staff issued its final report on the IFRS Work Plan in July 2012. While delineating the potential impact of incorporating IFRS into the financial reporting system for U.S. issuers, the report failed to make a recommendation for or against IFRS incorporation. In the report, the SEC Staff observed that most jurisdictions incorporate IFRS into their domestic reporting system by either (1) converging the jurisdiction's standards to IFRS without necessarily incorporating IFRS fully into the jurisdiction's reporting framework (convergence approach) or (2) endorsing IFRS into the jurisdiction's reporting framework on a standard-by-standard basis (endorsement approach). In other words, most jurisdictions do not simply designate IFRS as the standards to be used for domestic reporting purposes. As such, the jurisdiction can maintain control and flexibility regarding its financial reporting system. The SEC Staff, in the report, also discussed the concerns it has regarding the potential incorporation of IFRS in the U.S. for domestic issuers. These concerns include (1) the lack of consistent global application and enforcement of IFRS, (2) the insufficient development of IFRS, (3) the U.S. GAAP reference in laws and regulations and in a significant number of private contracts, (4) the substantial costs of conversion, and (5) the possible confusion to U.S. investors.

\section{CURRENT DEVELOPMENTS}

Based on the statements given by the SEC Chief Accountant James Schnurr at the Baruch College Financial Reporting Conference in May 2015, it appears that the SEC might make a decision really soon as Mr. Schnurr indicated that the SEC staff is currently developing a recommendation to the Commission and that hopefully some clarity could be provided to investors.

\footnotetext{
${ }^{3}$ In this section, the term "IFRS" refers to the version of IFRS (as issued by the IASB or as modified by a particular jurisdiction) described in the companies' financial statements.
} 
Mr. Schnurr also indicated that the SEC staff had received inquiries from a number of different constituents (preparers, investors, auditors, regulators and standard-setters) since his speech at the December 2014 AICPA National Conference on Current SEC and PCAOB Developments. Mr. Schnurr mentioned that some of the key questions raised by the constituents included (1) Is the Commission still committed to the objective of a single set of high-quality, globally accepted accounting standards? (2) If the Commission were to allow domestic issuers to include IFRS-based information without reconciliation, would that rulemaking be the Commission's final word on IFRS with respect to domestic issuers? and (3) Why would a company spend the time and money to provide IFRSbased information on a voluntary basis and what are the benefits of providing such information? Mr. Schnurr further pointed out that the main themes from the discussions with the constituents included (1) There is virtually no support to have the SEC mandate IFRS for all issuers; (2) There is little support for the SEC to provide an option allowing domestic issuers to prepare their financial statements under IFRS; and (3) There is continued support for the objective of a single set of high-quality, globally accepted accounting standards.

\section{USE OF IFRS AROUND THE WORLD}

Today, more than 120 jurisdictions require or permit the use of IFRS in varying degrees, either as originally issued by the IASB or as modified by a particular jurisdiction, for the preparation of financial statements by publicly held companies. According to the profile survey conducted by the IFRS Foundation, 116 out of the 140 jurisdictions profiled require IFRS for all or most domestic publicly accountable entities (listed companies and financial institutions) in their capital markets; twelve jurisdictions (Bermuda, Cayman Islands, Guatemala, Honduras, India, Japan, Madagascar, Nicaragua, Panama, Paraguay, Suriname, and Switzerland) permit, rather than require, IFRS; two jurisdictions (Saudi Arabia and Uzbekistan) require IFRS for financial institutions but not listed companies; one jurisdiction (Thailand) is in process of adopting IFRS in full; one jurisdiction (Indonesia) is in process of converging its national standards substantially with IFRS; and the remaining eight jurisdictions (Bolivia, China, Egypt, Guinea-Bissau, Macao, Niger, the U.S., and Vietnam) use national or regional standards. One point of note regarding these remaining eight jurisdictions is that China has adopted national accounting standards that are substantially converged with IFRS.

Because of the significant differences in the size of the economies of the jurisdictions profiled, the IFRS Foundation estimates that capital market investors and lenders in jurisdictions with about $58 \%$ of the world's GDP receive IFRS financial statements, even though over $90 \%$ of the 140 jurisdictions profiled require or permit IFRS. Nonetheless, IFRS is still more popular than U.S. GAAP from a GDP perspective.

\section{CONCLUSION}

Since the issuance of the 2007 Concept Release by the SEC, parties involved in the financial reporting system including investors, preparers, auditors, regulators, and educators have been waiting patiently for the SEC's decision on the potential move to IFRS by U.S. issuers. Many larger companies, in particular, multinational corporations prefer to be able to apply IFRS in the preparation of their financial statements as soon as possible. On the other hand, smaller and domestically-oriented companies question how the marginal benefits gained can justify the substantial costs incurred in switching to IFRS. The SEC has to strike a delicate balance between the interests of various parties involved. The SEC has indicated in its 2010 Statement that it will not incorporate IFRS into the financial reporting system for U.S. issuers unless such a change is in the best interest of U.S. investors and capital markets. Whatever decision eventually made by the SEC, hopefully, is indeed the most beneficial one for U.S. investors and capital markets.

\section{AUTHOR BIOGRAPHY}

Wing W. Poon is an associate professor of accounting at Montclair State University in New Jersey. He received his $\mathrm{Ph} . D$. in accounting from Louisiana State University in 1996. His research interests are in the area of financial reporting issues, international accounting standards, and taxation. His publications have appeared in Clarion Business and Economic Review, International Journal of Technology Policy and Law, Journal of Business \& Economics Research, and Practical Tax Strategies, among others. 


\section{ACKNOWLEDGEMENTS}

This paper is an update to my previous paper, "Incorporating IFRS into the U.S. Financial Reporting System," Journal of Business \& Economics Research, 10(5), 303 - 311, published in 2012.

\section{REFERENCES}

IFRS Foundation. 2015. Analysis of the IFRS Jurisdiction Profiles. Available at http://www.ifrs.org/Use-around-theworld/Pages/Analysis-of-the-IFRS-jurisdictional-profiles.aspx

Poon, Wing. 2012. Incorporating IFRS into the U.S. Financial Reporting System. Journal of Business \& Economics Research, $10(5), 303-311$.

Schnurr, James. 2014. Remarks before the 2014 AICPA National Conference on Current SEC and PCAOB Developments. Available at http://www.sec.gov/News/Speech/Detail/Speech/1370543609306 2015. Remarks before the 2015 Baruch College Financial Reporting Conference. Available at http://www.sec.gov/news/speech/schnurr-remarks-before-the-2015-baruch-college-financial-reporti.html

Securities and Exchange Commission (SEC). 2007a. Concept Release on Allowing U.S. Issuers to Prepare Financial Statements in Accordance with International Financial Reporting Standards. Release No. 33-8831. Washington, D.C.: SEC. 2007b. Acceptance from Foreign Private Issuers of Financial Statements Prepared in Accordance with International Financial Reporting Standards without Reconciliation to U.S. GAAP. Release No. 33-8879. Washington, D.C.: SEC. 2008. Roadmap for the Potential Use of Financial Statements Prepared in Accordance with International Financial Reporting Standards by U.S. Issuers, Release No. 33-8982. Washington, D.C.: SEC. 2010. Commission Statement in Support of Convergence and Global Accounting Standards, Release No. 33-9109. Washington, D.C.: SEC.

Staff of the Securities and Exchange Commission (SEC Staff). 2011a. Exploring a Possible Method of Incorporation. Washington, D.C.: SEC Staff. 2011b. A Comparison of U.S. GAAP and IFRS. Washington, D.C.: SEC Staff. 2011c. An Analysis of IFRS in Practice. Washington, D.C.: SEC Staff. 2012. Final Staff Report. Work Plan for the Consideration of Incorporating International Financial Reporting Standards into the Financial Reporting System for U.S. Issuers. Washington, D.C.: SEC Staff. 


\section{NOTES}

